\title{
Impact of FDI on Economic Growth, Employment, and Poverty Reduction in Ghana
}

\author{
Shadrach Ato-Mensah, Wei Long \\ School of Economics, Wuhan University of Technology, Wuhan, China \\ Email:shadrachatomensah@gmail.com
}

How to cite this paper: Ato-Mensah, S., \& Long, M. (2021). Impact of FDI on Economic Growth, Employment, and Poverty Reduction in Ghana. Open Journal of Business and Management, 9, 1291-1296. https://doi.org/10.4236/ojbm.2021.93069

Received: March 14, 2021

Accepted: May 25, 2021

Published: May 28, 2021

Copyright (C) 2021 by author(s) and Scientific Research Publishing Inc. This work is licensed under the Creative Commons Attribution International License (CC BY 4.0).

http://creativecommons.org/licenses/by/4.0/

\begin{abstract}
The Republic of Ghana is one of the most economically developed countries in West Africa. In the past 10 years, Ghana's economy has maintained a sound momentum and strong economic growth. The Republic of Ghana regards foreign direct investment (FDI) as a key factor in promoting its economic growth. This article separates economic growth, employment and poverty reduction, and focuses on the single impact of foreign direct investment (FDI) on Ghana's economic growth, employment and poverty. The research in this article shows that foreign direct investment can promote the economic development of Ghana, and foreign direct investment can increase employment opportunities in Ghana and reduce poverty at the same time. Finally, this article gives corresponding recommendations based on the research conclusions: In maintaining sustainable economic growth, favorable policies should be adopted to encourage and support Ghana, so as to attract more foreign direct investment to stimulate economic growth.
\end{abstract}

\section{Keywords}

FDI, Economic Growth, Employment, Poverty Reduction, Ghana

\section{Introduction}

\subsection{Research Background}

Among the West African countries, the Republic of Ghana has a relatively developed economy. The three traditional export products of gold, cocoa and timber are the economic pillars of the Republic of Ghana (Wakyereza et al., 2017). In the late 1990s, due to the impact of external factors such as gold and cocoa prices on the international market, the Republic of Ghana experienced an economic downturn, increased fiscal deficits, and a sharp depreciation of its currency. After the Kufuor regime came to power, it focused on stabilizing and 
developing the economy, strengthened macro-control, formulated temporary budgets, fully implemented a free and open economic policy, and promoted the development of private enterprises. The price of gold and cocoa on the international market began to gradually rise. Ghana's economy has also improved, the value of the currency has gradually stabilized. As a result of the formulation and implementation of a series of development strategies, Ghana's economy has achieved unprecedented development in the past few years, maintaining an annual economic growth rate of $6 \%$ and becoming the leader in economic development in West Africa. During his visit to Ghana, World Bank President Zoellick said that in the past 10 years, Ghana's economy has maintained a strongly economic growth.

In the process of Ghana's economic development, Ghana has always regarded foreign direct investment (FDI) as a key factor in promoting its economic growth. Musah et al. (2018) pointed out that about $80 \%$ of the newly created jobs in Ghana from 2008 to 2018 came from abroad investment in Ghana. And most of these FDIs are concentrated in the manufacturing, construction and general trade sectors, providing many employment opportunities for Ghana and promoting the growth of the Ghanaian economy. On the basis of existing research, this article separates economic growth, employment and poverty reduction, focusing on the single impact of foreign direct investment (FDI) on Ghana's economic growth, employment and poverty.

\subsection{Literature Review}

Osei et al. (2019) pointed out that FDI can be regarded as a form of foreign aid. The core goal of official development international aid is not only to promote economic growth, but also to reduce poverty. Larry \& Hlovor (2019) pointed out that if a developing country actively implements reform and opening policies to promote economic growth, then active political assistance can play a supporting role in domestic economic development. Tee et al. (2017) pointed out that the effectiveness of international aid is well known. International aid will bring some positive effects to developing countries, such as providing public goods, increasing human capital, alleviating huge debts, and promoting the development of some technologies to a certain extent. On the other hand, foreign aid also faces many challenges and criticisms. Foreign direct investment and other aid funds always ignore the industries or enterprises in developing countries that are in urgent need of funds, and are allocated to those places where there is no relative shortage of funds, resulting in uneven distribution.

In general, from a macro perspective, FDI has a positive effect on economic development and the balanced development of the labor market. Awunyo \& Sackey (2018) research shows that for every $1 \%$ increase in FDI, actual employment can increase by $0.008 \%$. Mohammed (2018) research shows that FDI can create a large number of employment opportunities in the short-term. The impact of medium-term FDI on total employment is not yet clear. The impact of 
long-term FDI on employment is positive, but it depends on the spillover effect.

\section{The Main Forms of FDI}

\subsection{Joint Venture}

A joint venture refers to an enterprise established in Ghana by a foreign company, enterprise, economic organization or individual in accordance with relevant regulations, and a local company, enterprise or other economic organization in Ghana that jointly invests in it. The characteristics of a joint venture mainly include: the joint venture has the status of a legal person, the parties to the joint venture jointly contribute capital, joint management, risk sharing, and profit sharing. The form of the operating enterprise is a limited liability company. The remaining assets are liquidated at the expiration of the joint venture and the capital contribution is Proportional distribution.

\subsection{Cooperative Enterprises}

A cooperative enterprise refers to an enterprise jointly established in Ghana by a foreign company, enterprise, economic organization or individual in accordance with relevant regulations and a Ghanaian company, enterprise or other economic organization in Ghana. Cooperative business enterprises can adopt legal person type and unincorporated type, and the form of enterprise can adopt limited liability and unlimited liability.

\subsection{Wholly Foreign-Owned Enterprises}

A wholly foreign-owned enterprise refers to a foreign company, enterprise, economic organization, or individual established in accordance with relevant regulations. Its characteristics mainly include: the enterprise has the status of a legal person, all capital is owned by foreign investors, and the organization form is generally a limited liability company. When the foreign-funded enterprise terminates, Shall go through the cancellation of registration with the relevant agencies and departments, and hand in the business license for cancellation.

\section{The Impact of FDI on Ghana}

\subsection{The Impact of FDI on Ghana's Economic Growth}

A United Nations report showed that FDI in Africa increased by 13\% in 2019, reaching 32 billion U.S. dollars, reversing the two-year downward trend. Some African countries are better than others. South Africa performed well, with FDI reaching nearly US $\$ 4.2$ billion.

The impact of FDI on Ghana's economic growth mainly includes the following four points:

1) Make up for the lack of domestic construction funds. The Republic of Ghana's investment restrictions are still very large, and the use of FDI has effectively solved the problem of insufficient funding sources in Ghana. In recent 
years, with the continuous changes in Ghana's policy of utilizing foreign capital, the proportion of FDI has steadily increased.

2) Promote technological progress in the Republic of Ghana. The introduction of technology through direct investment by multinational companies, with the transfer of technology, capital supply, technology absorptive capacity, market development capacity and corresponding management knowledge, as well as further technology development capacity or new technology provision capacity will follow into the Republic of Ghana market.

3) Promote the development of foreign trade. FDI has expanded the scale of Ghana's foreign trade. Under the influence of technology spillover effects through FDI, Ghana's related industries have developed rapidly, enhancing the competitiveness of products in the international market, and the export of foreign-invested enterprises has greatly optimized the structure of Ghana's import and export commodities.

4) Promote the growth of Ghana's economy. Through FDI, Ghana can increase new varieties of capital goods, thereby promoting economic growth. Studies have shown that an average increase of one unit of FDI can boost the growth of 48 units of GDP. The investment in technology, management, and knowledge has greatly improved Ghana's technical management and employee knowledge, and promoted economic growth.

\subsection{The Impact of FDI on Employment in Ghana}

According to the employment data of the World Bank, among the 1506 newly registered projects in Ghana from 2009 to 2019, more than 300 projects were invested by Chinese companies. It is these new projects that have made great contributions to solving the employment problem in Ghana. This is also an important manifestation of FDI's promotion of employment in Ghana. Compared with expatriates, Ghanaians accounted for most of the new jobs created by the project, and the number of new jobs created from 2009 to 2019 also increased significantly. This is also the direct employment effect of FDI.

However, the impact of FDI on employment is restricted by multiple factors. The short-term impact on employment mainly depends on the way FDI enters. Generally, there are two main ways for FDI to enter the host country: one is new investment, and the other is to merge existing enterprises in the host country. Usually investors enter the host country through mergers and acquisitions in developed countries, while in developing countries they enter the host country mainly through new investment. Mergers and acquisitions usually lead to business integration and personnel deployment of the acquired company, as well as a large number of layoffs. And new investment usually absorbs a lot of labor. In order to reduce costs, multinational companies will inevitably localize their employees. Except for individual senior managers who are called from their home countries, other employees usually employ local labor, so this type of FDI can expand employment opportunities. 


\subsection{The Impact of FDI on Poverty Reduction in Ghana}

FDI's contribution to poverty eradication in Ghana is mainly based on the above two points. After FDI promotes economic growth and creates a large number of new jobs, it naturally reduces poverty.

On the one hand, economic growth has an impact on poverty eradication. Economic growth can be divided into employment growth and output growth. Cities with higher employment growth are the most successful in poverty eradication, especially in the areas of health care, construction, and retail. Output growth has no effect on urban poverty in the short term, and will only affect the wage growth of the high-income class. However, in the long run, output growth can lead to employment growth. On the other hand, poverty eradication contributes to economic growth and can bring huge economic benefits to Ghana. First, eradicating poverty can make better use of people's skills, knowledge, and experience, thereby increasing productivity. Second, eliminating poverty can increase income, increase consumption, meet local economic needs, and directly benefit local businesses in Ghana.

\section{Conclusion and Recommendations}

In the past few decades, the Ghanaian government has initiated several policies to attract FDI because it can bring many benefits, so this article separates economic growth, employment and poverty reduction, focusing on the single impact of FDI on Ghana's economic growth, employment and poverty (Amoako \& Insaidoo, 2019).

This article points out that higher FDI is vital to Ghana's economic growth, employment increase and poverty reduction, because there is a one-way link from FDI to economic growth, and higher levels of FDI are very important for achieving economic growth (Adongo et al., 2018).

Therefore, policies for economic growth and development should focus on solving the factors that hinder Ghana from attracting FDI. In terms of maintaining sustainable economic growth, favorable policies should be given to encourage and support Ghana so as to attract more FDI to stimulate economic growth.

\section{Conflicts of Interest}

The authors declare no conflicts of interest regarding the publication of this paper.

\section{References}

Adongo, S. A., Chen, L., Hu, X., \& Obobisa, E. S. (2018). Mechanisms of Fdi Technology Transfer and Economic Growth in Ghana.

Amoako, S., \& Insaidoo, M. (2021). Symmetric Impact of Fdi on Energy Consumption: Evidence from Ghana. Energy, 223, Article ID 120005.

https://doi.org/10.1016/j.energy.2021.120005 
Awunyo-Vitor, D., \& Sackey, R. A. (2018). Agricultural Sector Foreign Direct Investment and Economic Growth in Ghana. Journal of Innovation and Entrepreneurship, 7, Article Number: 15. https://doi.org/10.1186/s13731-018-0094-3

Larry, M. R., \& Hlovor, I. K. (2019). Elections, Foreign Direct Investment, and Economic Growth in Ghana's Fourth Republic: 1993 to 2016. International Journal of Economics and Financial Research, 5, 9-15. https://doi.org/10.32861/ijefr.51.1.8

Mohammed, A. (2017). The Effect of Foreign Direct Investment (FDI) on Infrastructure Development in Ghana.

Musah, A., Gakpetor, E. D., Nana, S., Kyei, K., \& Akomeah, E. (2018). Foreign Direct Investment (FDI), Economic Growth and Bank Performance in Ghana.

Osei, A. E. (2019). An Assessment of the Impact of Foreign Direct Investment on Employment: The Case of Ghana's Economy. The Journal of Social Sciences Research, 5.

Tee, Evans, Larbi, Frank, Johnson, \& Rebecca. (2017). The Effect of Foreign Direct Investment (fdi) on the Ghanaian Economic Growth. Journal of Business \& Economic Development.

Wakyereza, R. (2017). The Impact of Foreign Direct Investment on Economic Growth, Employment and Poverty Reduction in Uganda. 